\title{
PŘíNOS GEOFYZIKÁLNÍCH MĚŘENÍ PRO POZNÁNÍ TEKTONIKY A SESUVŮ VE ŠLAPANICÍCH
}

\author{
Contribution of methods for near-surface geophysical survey for tectonics and landslides \\ in Šlapanice town
}

\author{
Pavla Tomanová Petrová', František Hubatka², Oldřich Krejčí1 \\ 'Česká geologická služba, Leitnerova 22, 65869 Brno; e-mail:pavla.petrova@geology.cz \\ ${ }^{2}$ Kolej Consult \& servis spol. s r. o., Křenová 35, 60200 Brno
}

(24-41 Šlapanice)

Key words: Carpathian Foredeep, tectonic, geophysics, georadar, geoelectricity, remediation

\begin{abstract}
In the area of the Šlapanice school buildings a large frontal landslide in Lower Badenian clay covered by loesses and anthropogenic sediments was documented. Length of the landslide is ca $200 \mathrm{~m}$, width at the base up to $720 \mathrm{~m}$, thickness of the body of the landslide based on geophysical research reaches to $10 \mathrm{~m}$. The landslide is a complex body consisting of older and active parts. The school buildings were founded in old landslide originally.

Georadar (two profiles) and geoelektric (one profile) measurements were used for geotechnical evaluation of the landslide. Multi electrode cable tomography (ERT) and dipole electromagnetic conductivity survey (DEMP) were used from geoelectric method.

Closely the northern part of the building was measured and interpreted geological-geophysical profile PF0 which was constructed based on georadar measurement and hydrogeological borehole VS-1, the sharp boundary between sediments of the Lower Carboniferous and the Lower Badenian of the Carpathian Foredeep was found. There were intepreted two fault systems of SW-NE direction taking place parallel to the margin of the basin. In the profile PF1 the structure of the landslide in detail was documented. Due to geophysical measurements and study of the borehole database a new fault system within the school buildings area was intepreted.
\end{abstract}

Úvod

$\mathrm{V}$ rámci zpracování geotechnického posudku a posouzení stability svahu na akci „Snížení energetické náročnosti ZŠ Šlapanice “byl proveden v roce 2012 geofyzikální a geotechnický průzkum v širším okolí základní školy Šlapanice (Gartner 1999, Hubatka 2012, Veselý et al. 1990). Na tento průzkum navázalo měření posunů a deformací v pavilonu A (hlavní školní budově) a mapování stavu podloží v prostoru hřiště ve svahu nad školou. Geofyzikální měření bylo realizováno firmou Kolejconsult \& servis, s. r. o. metodou georadaru a geoelektrického měření. Cílem tohoto př́spěvku je seznámit s inženýrsko-geologickou situací na lokalitě.

V březnu 2012 byl areál školy a její okolí zdokumentován pracovníky ČGS. Bylo zjištěno, že na budovách školy ve Šlapanicích se vyskytují četné trhliny. Školní budovy jsou plošně rozsáhlé a při výstavbě bylo nutné pro ně vytvořit plošiny, zčásti na zhutněných násypech. Pro zarovnání terénu byly použity také navážky ze skrývky blízké cihelny. Svah byl lidskými zásahy značně upravován. Na školních budovách, založených na jednotlivých patkách, byly v průběhu času pozorovány trhliny se zhoršující se tendencí. Trhliny se objevují zhruba od roku 1989, v roce 1990 bylo provedeno měření svislých odchylek stěn a nosných prvků. Během prrístavby krytého bazénu v roce 1979 byl pozorován dílčí sesuv, který byl stabilizován. Pưvodní starší sesuv, který byl považován za dočasně uklidněný, byl zčásti postupnými stavebními zásahy aktivován. Současně vlivem nerovnoměrného sedání podloží došlo k narušování některých budov školy. Detailní statickou pasportizací a geofyzikálním průzkumem byl zjištěn skutečný stav bezprostředního podloží základových patek školních budov a definování směru zón, roznášejících napětí v podkladu a způsobujících porušení budov. Území se nachází v Pracké pahorkatině, v okrsku Šlapanická pahorkatina. Sesuv se nachází v rozmezí nadmořských výšek cca 225 až 250 m. Nejbližším významných vrcholem je Žuráň (286,54 m n. m.), který leží asi 1 km daleko směrem na SV. Sklon svahu dosahuje až $6^{\circ}$.

\section{Geologická charakteristika oblasti (obr. 1)}

Zájmové území se nalézá v okrajové části karpatské předhlubně Západních Karpat. 3D pohled reliéfu dokládá strmější svahy na výchozech spodnokarbonských klastik oproti mírnějším sklonům terciérního pokryvu. Hlubší podloží je tvořeno horninami brněnského masivu, resp. amfibol-biotitickým granodioritem. V jeho nadloží leží sedimenty paleozoika. Počátek paleozoické sedimentace tvoří bazální devonská klastika představovaná pískovci a křemennými slepenci. Sled pokračuje 400 m mocnými vilémovickými vápenci macošského souvrství a karbonátová sedimentace je ukončena 100 m mocnými hádsko-ř́čskými vápenci líšeňského souvrství. Spodnokarbonskou sedimentaci představuje $300 \mathrm{~m}$ račických slepenců myslejovického souvrství, které v okolí Šlapanic vystupují na povrch.

Paleozoické sedimenty jsou překryty pokryvem spodnobadenských jílů, tzv. téglů. Jedná se o masivní modrošedé vápnité prachovité jílovce s bohatou mikrofaunou (viz popis společenstva in Buriánek - Tomanová Petrová 2013). V místech, kde se paleozoické horniny přibližují $\mathrm{k}$ dnešnímu povrchu, nedocházelo ke vzniku starých sesuvů, i když jsou zde větší sklony svahů. V oblasti svahů na levém břehu Říčky se však v centru Šlapanic tyto sedimenty 


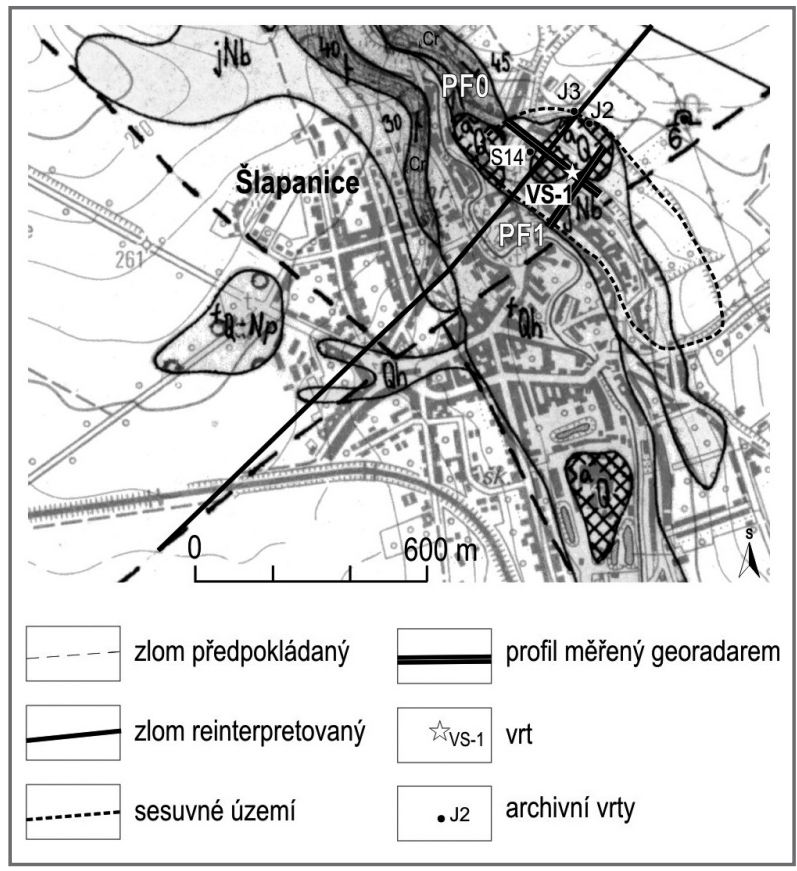

náhle noří do hloubky přes $80 \mathrm{~m}$. Svahy na neogenních sedimentech ztrácejí stabilitu a jsou náchylné k sesouvání i při malých sklonech (Poul et al. 2010).

Podle dostupných archivních vrtů, situovaných v širším okolí zájmového objektu, se podložní neogenní jílovitý komplex nachází v hloubce od 0,7 do 4,6 m. Některé vrty (např. S-14, J-2 a J-3), hlavně na z. a s. straně školních objektů, zastihly písčité proplástky. Na jižní straně budov školy byly zachyceny polohy štěrků. Hladina podzemní vody byla naměřena v hloubce 1,9 až $6,4 \mathrm{~m}$. Dále bylo využito výsledků z hlubokého hydrogeologického vrtu VS-1 (Mělníčková 2007).

\section{Popis sesuvného území}

Jedná se o rozsáhlý frontální sesuv podél hrany svahu neogenních jílovitých sedimentů, tzv. téglů, v horní části překrytých sprašemi, sprašovými hlínami a navážkami. Délka sesuvu činí zhruba $200 \mathrm{~m}$, šírka u paty až $720 \mathrm{~m}$. Mocnost těla sesuvu podle geofyzikálního průzkumu dosahuje $10 \mathrm{~m}$. Na vznik staršího sesuvného území měl vliv zlom, který porušuje kulmské podloží (obr. 1). Zatímco v prostoru na SZ od zlomu je podloží uložené mělce nebo vystupuje na povrch, na V od něj nebylo vrtem VS-1 dosaženo kulmské podloží $\mathrm{v}$ hloubce 81 m (nadmořská výška $240 \mathrm{~m}$ ).

Jedná se o staré sesuvné území na svahu se spodnobadenskými sedimenty (stáŕí asi 16 miliónů let), které mohlo vzniknout již v terciéru
Obr. 1: Lokalizace sesuvného území v geologické mapě $1: 25000$ 24-431 Šlapanice (sensu Brzobohatý 1987) s vyznačením reinterpretovaného zlomového systému, profilů na geofyzikálních liniích PF0 a PF1 měřených georadarem a vrtu VS-1 [legenda: ${ }^{\mathrm{a}} \mathrm{Q}$ - antropogenní uloženiny, ${ }^{\mathrm{f}} \mathrm{Qh}$ - fluviální převážně písčitohlinité sedimenty, Qh - deluviofluviální sedimenty, ${ }^{\mathrm{f}} \mathrm{Q}-$ - $\mathrm{Np}$ - fluviální písčité štěrky (pleistocén-pliocén), $\mathrm{Nb}$ - baden spodní mořský, vápnité jíly, podřadně písky, ${ }_{\mathrm{k}} \mathrm{Cr}-$ myslejovické souvrství, račické slepence (petromiktní), svrchní visé].

Fig. 1: Localization of landslide area in geological map $1: 25000$ 24-431 Šlapanice (sensu Brzobohatý 1987) with sketch of reinterpreted fault system, profiles on geophysical lines PF0 and PF1 measured by georadar and the borehole VS-1 [legend: ${ }^{\mathrm{a}} \mathrm{Q}$ - anthropogenic sediments, ${ }^{\mathrm{f}} \mathrm{Qh}$ - fluvial mainly sandclayey sediments, $\mathrm{Qh}$ - deluviofluvial sediments, ${ }^{\mathrm{f}} \mathrm{Q}-\mathrm{Np}$ - fluvial sandy gravels (Pleistocene-Pliocene), $\mathrm{Nb}$ - Lower Badenian marine, calcareous clays, less sands, ${ }_{k} \mathrm{Cr}-$ Myslejovice Formation, Račice conglomerates (petromickt), Upper Visé].

(Poul et al. 2010). Na těchto svazích se na území brněnské aglomerace sesuvy vyskytují velmi často.

\section{Metodika měření}

Georadarové měření bylo realizováno geologickým radarem Pulse EKKO PRO s frekvencí $50 \mathrm{MHz}$ a pulsním napětím $1000 \mathrm{~V}$. Naměřená data na radarových profi-

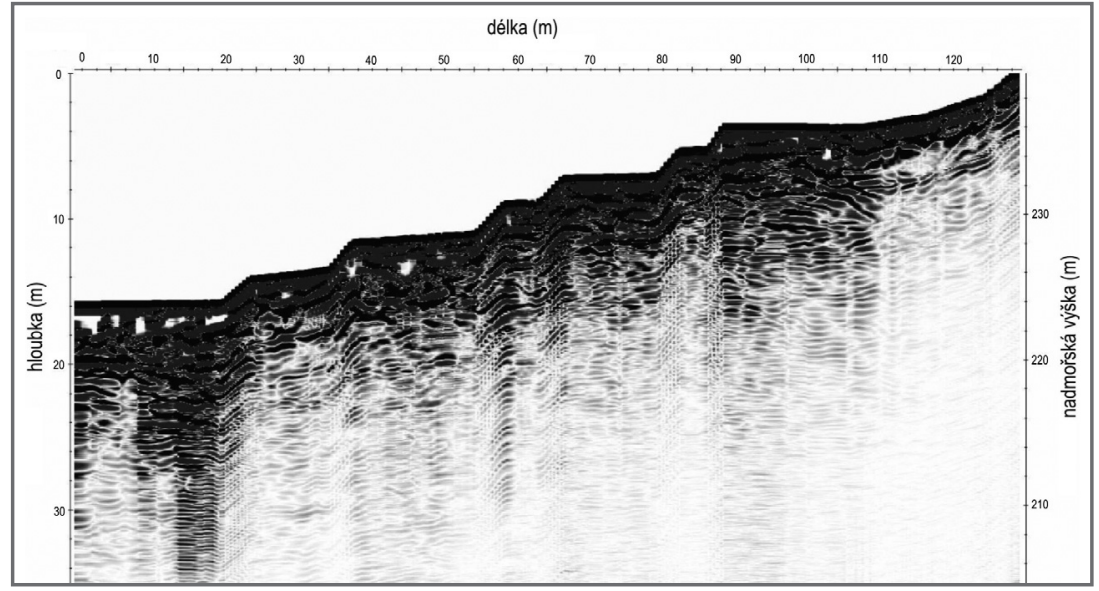

Obr. 2: Georadarový profil po linii PF1 podél v. strany školní budovy ve směru JZ-SV. Fig. 2: Georadar profile PF1 along the school building in the direction SW-NE.

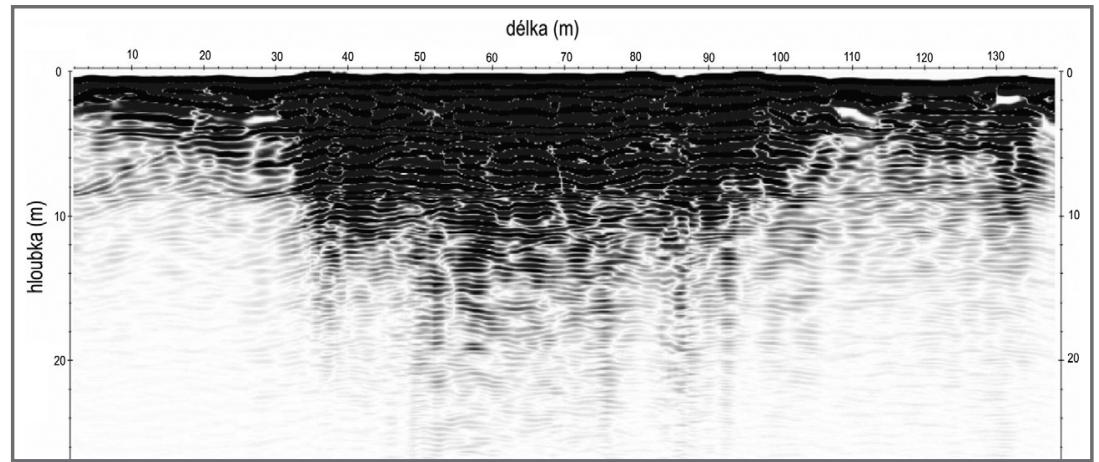

Obr. 3: Georadarový profil po linii PF0 objektem školní budovy ve směru SZ-JV.

Fig. 3: Georadar profile PF0 through the school building in the direction NW-SE. 
lech byla zpracována s použitím programového souboru EKKO SOFTWARE a REFLEXW 6.0, Sandmeier 2011. To zahrnovalo patřičnou dynamickou úpravu signálu, filtraci, migraci, výpočet a zavedení $2 \mathrm{D}$ rychlostního modelu a transformaci časového řezu na hloubkový. $\mathrm{Na}$ vybraných geofyzikálních liniích PF1 a PF0 (obr. 2 a 3) jsou interpretována hlavní geologická rozhraní a projevy svahových deformací.

Dále bylo provedeno geoelektrické měření metodou mnohaelektrodové tomografie ERT (multikabel) a dipólové elektromagnetické profilování DEMP. Za účelem stanovení ulehlosti zemin byly realizovány dvě sondy dynamické penetrace.

\section{Výsledky měření \\ Geoelektrická měření (obr. 4)}

Změny měrných odporů člení řez vertikálně na tř̌i úrovně. Téměř v celé délce profilu byla zachycena př́ípovrchová vrstva vysokých měrných odporů (nad $50 \Omega \cdot \mathrm{m}$ ) o mocnosti okolo $1,5 \mathrm{~m}$. Jedná se o navážky a stabilizované zeminy. V dalším horizontu se až po úroveň $220 \mathrm{~m} \mathrm{n}$. $\mathrm{m}$. (hloubka asi $5 \mathrm{~m}$ ) střídají polohy vyšších odporů (metráže 35-50) s nízkými (metráže 60-75) a opět vyššími u bodu 80 , kde je patrný náznak prohnutí vrstev. Zóny vyšších odporů by měly odpovídat výskytu písčitějších zemin na rozdíl od oblastí nízkých odporů, které obecně patří k jemnozrnným, jílovitým zeminám. Litologická změna v hlubších partiích se nachází ve střední části řezu na metrážích zhruba 50-65, kde se měrné odpory zvyšují na $20-40 \Omega \cdot m$ a indikují písčité polohy. V okolí převažují nízké měrné odpory (do $10 \Omega \cdot m$ ) naznačující výskyt převážně jílovitých zemin. Ve střední části profilu bylo zachyceno zlomové pásmo, projevující se přerušením a strukturním posunem vrstvy nízkých odporů.

\section{Radarová měření}

V profilu PF1 (obr. 2) je vyjádřena míra reflexivity, vyjádřená sytostí černé barvy, která odráží míru narušení a nestabilitu podloží. Na georadarovém profilu PF0 vedeném napříc školní budovou (obr. 3) ve směru Z-V je patrná mísovitá struktura, která ukazuje na zhoršení kvality podloží - jeho degradaci vlivem dlouhodobého zatékání vody pod základy objektu a to do hloubky minimálně $10 \mathrm{~m}$.

Obr. 6: Plošné vymezení okraje kulmu, karpatských zlomů a aktivního sesuvu.

Fig. 6: Area demarcation of the margin of the Culmian, Carpathian faults and active landslide.

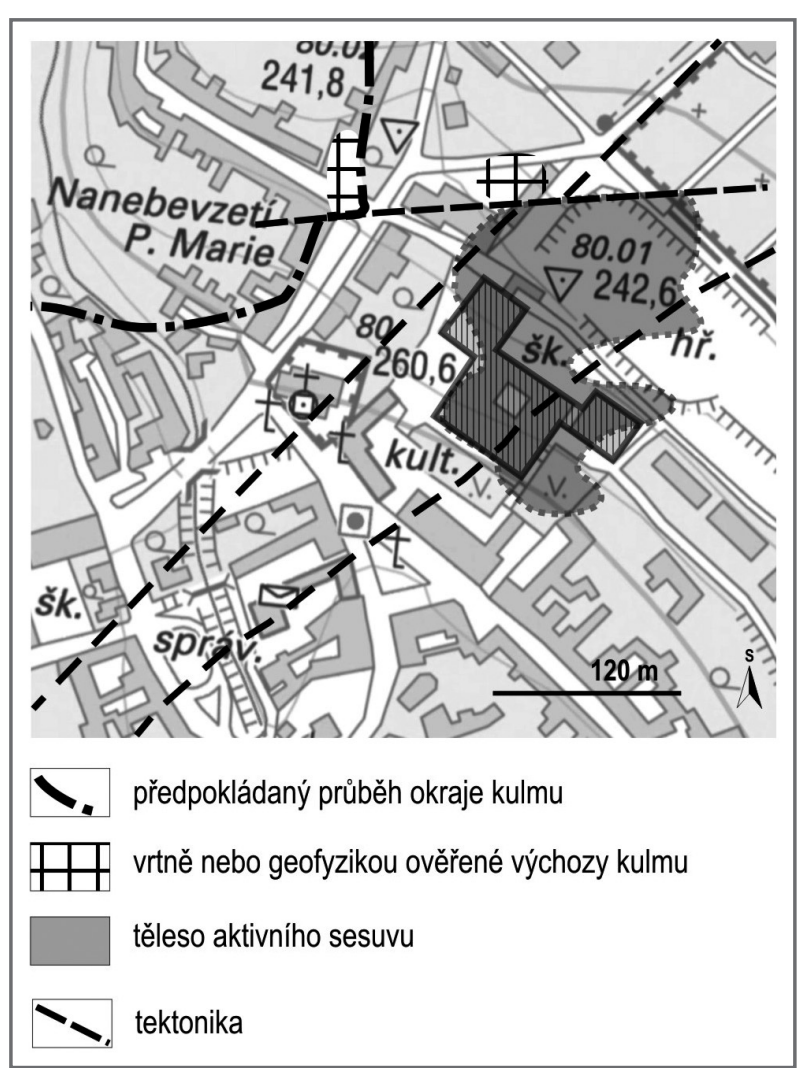




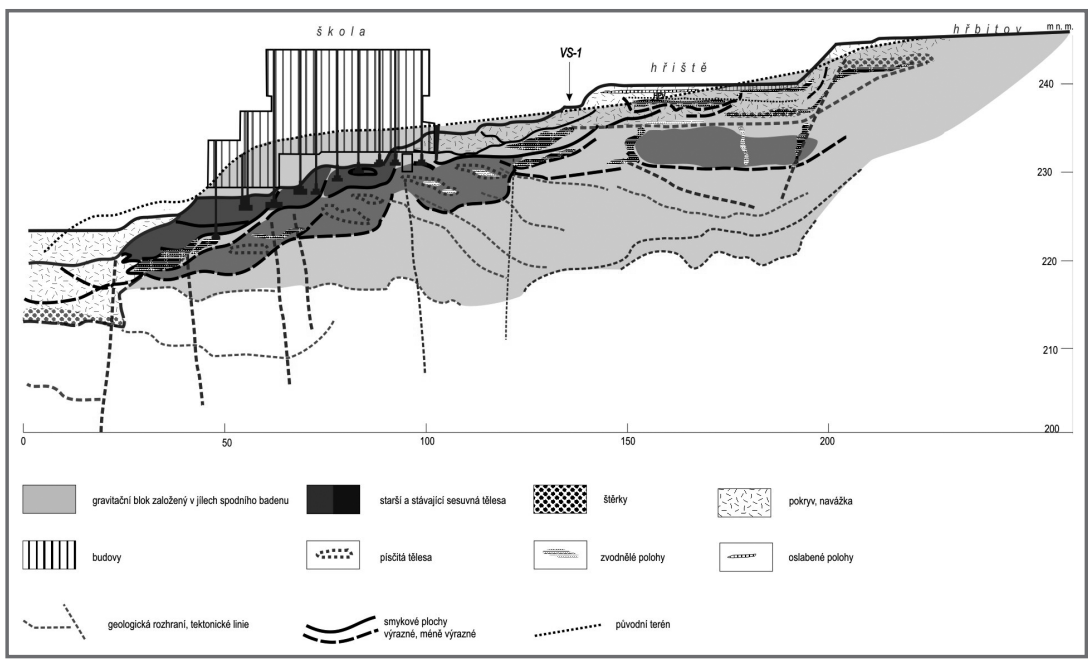

Obr. 7: Geologicko-geofyzikální řez po linii PF1. Vymezení sesuvného tělesa. Fig. 7: Geological-geophysical cross-section PF1. Marking of landslide body. potokem Říčka. V důsledku starší říční eroze ve svrchním pleistocénu došlo k odlehčení paty svahu v jeho j. části. Tím se v důsledku působení laterálních sil (pravděpodobně po vrstevních plochách) vytváří rozsáhlé gravitační těleso, jehož bazální plochy leží až v hloubce okolo $20 \mathrm{~m}$. $\mathrm{V}$ čele gravitačního bloku se $\mathrm{v}$ zóně zvětrání vytvářejí dílčí aktivní sesuvná tělesa (obr. 7). Báze starších sesuvů leží v hloubce asi $10 \mathrm{~m}$. V hloubce 1 až $5 \mathrm{~m}$ se nachází aktivní sesuvné těleso př̀evážně jílovitého charakteru, ve kterém jsou patrné projevy tečení a dalších svahových deformací. Čelo sesuvu se nachází asi $10 \mathrm{~m}$ pod j. terasou školy. Zájmový objekt ZŠ je založen do tohoto sesuvného tělesa.
V geologicko-geofyzikálním řezu (obr. 5) na s. straně objektu, který byl sestaven podle georadarového měření po geofyzikální linii PF0 a hydrogeologického vrtu VS-1, byla upřesněna pozice kontaktu mezi paleozoikem (spodní karbon) a neogenní výplní (spodní baden) karpatské předhlubně. Dále jsou zde vymapovány dva zlomy karpatského směru, které probíhají souběžně s okrajem pánve (obr. 6).

V geologicko-geofyzikálním řezu vedeném po geofyzikální linii PF1 (obr. 7), který byl situován na v. straně objektu, je podrobně rozpracována struktura sesuvu. Byl zkonstruován na podkladě podrobné analýzy georadarového profilu, křižujících odporových řezů a výsledků dynamických penetrací.

Z geodynamického modelu vyplývá, že objekt ZŠ je založen v místě starého sesuvu, který je uložený v hloubce 5 až $10 \mathrm{~m}$. Jedná se o geologické těleso, ve kterém se vyskytuje řada písčitých vložek čočkovitého tvaru. Tato tělesa jsou uložena subhorizontálně nebo mírně vybíhají $\mathrm{k}$ povrchu. Na tomto starším sesuvu leží aktivní vrstva zvětralých jílů, které jsou podle dynamického projevu velmi plastické a deformované. Jedná se o aktivní sesuvné těleso o rozměrech $120 \times 120 \mathrm{~m}$. Z pozice základových prvků je patrné, že kromě obvodových patek na j. stěně je objekt založen v aktivní části sesuvu. Voda se do sesuvu dostává z horních partií svahu a to pod bází spraší nebo po bázi zvětralého podloží neogénu. $\mathrm{V}$ místě aktivního sesuvu se voda postupným přetékáním po dílčích písčitých tělesech vsakuje a hromadí na jeho čele, tj. v prostoru před j. terasou školy.

Z plošné korelace georadarových dat vyplývá, že v sv. rohu pozemku školy se nachází dynamicky aktivní zóna, nejvýrazněji se projevující v hloubkovém intervalu 5 až $6 \mathrm{~m}$, pravděpodobně se jedná o hlavní přítok vody do podloží objektu.

\section{Závěr}

Sesuv je založen ve spodnobadenských jílech - „téglech“, uložených v lokální elevační struktuře svahu nad
Čelní - jižní řada patek - je založena 0,5 až $1,0 \mathrm{~m}$ pod aktivní smykovou plochu. $Z$ tohoto pohledu zde existuje křehký rovnovážný stav.

V rámci geofyzikálního průzkumu byla vymapována významná tektonická linie, paralelní s okrajem flyšových Karpat, jejíž jedna větev probíhá pod areálem základní školy ve Šlapanicích. Podle strukturních projevů zaznamenaných v geofyzikálních profilech se může jednat o zlom s horizontálním pohybem.

Podrobnou analýzou vrtných a geofyzikálních dat byl vymezen okraj vyšší kry spodnokarbonských hornin. $\mathrm{V}$ rámci této analýzy byla dále interpretována indikace zlomu Z-V, která prochází vrcholovou partií svahu a definuje odlučnou zónu badenského sesuvu. Tento zlom s charakterem pravostranného posunu je dobře patrný i v 3D pohledu na zájmové území, zvláště pak v meandru erozního uzávěru, probíhajícího v patě zájmového svahu. Vlastní sesuvné těleso leží v prostoru vymezeném těmito dvěma zlomovými systémy.

V prrípadě nezahájení stabilizačních opatření bude docházet k dalšímu vývoji sesuvného území a zvýšení jeho rizikovosti. Stabilizační opatření budou spočívat především ve vybudování trvalých odvodňovacích prvků. V dolní části svahu se uvažuje o výstavbě zátěžového tělesa.

Po statické pasportizaci všech školních objektů bylo doporučeno osadit mělké značky pro sledování pohybů i mimo budovy školy, spolu se zpracováním projektu stabilizačních opatření. Pravidelné monitorování změn na budovách školy a v okolním terénu by zaznamenalo vývoj změn na konstrukci a v podloží objektu. Po výstavbě stabilizačních prvků by pak tento monitorovací systém umožnil potvrzení jejich účinnosti.

\section{Poděkování}

Článek vznikl za podpory projektu č. 390003 Základní geologické mapování území ČR 1: 25000 - Brněnsko. Děkujeme RNDr. Karlu Kirchnerovi za kritické posouzení rukopisu. 


\section{Literatura}

Brzobohatý, R. (1987): Základní geologická mapa $1: 25000$ 24-431 Šlapanice. - MS, ČGS Praha.

Buriánek, D. - Tomanová Petrová, P. (2013): Chemické složení řasových písčitých vápenců a vápnitých pískovců. - Geologické výzkumy na Moravě a ve Slezsku, 7-12.

Gartner, O. (1999): Znalecký posudek - Stavebně-technické posouzení současného stavu objektu základní školy ve Šlapanicích (součástí je opis posudku prof. Dr. Ing. Vojtěcha Mencla, DrSc., z roku 1979).

Hubatka, F. (2012): Zpracování geotechnického posudku a posouzení stability svahu na akci: Snížení energetické náročnosti ZŠ Šlapanice. Geofyzikální a geotechnický průzkum. - MS, Kolej Consult \& servis spol. s r. o., Křenová 36, Brno.

Mělníčková, P. (2007): Závěrečná zpráva hydrogeologického průzkumu, hydrogeologické vyjádření a projekt vrtané studny. - MS, HS. geo. Brno.

Poul, I. - Krejčí, O. - Hubatka, F. (2010): Fosilní sesuvy v neogenních mořských jílech na severu brněnské aglomerace - podceněný aspekt pro založení obytných staveb. - Geologické výzkumy na Moravě a ve Slezsku 17, 195-198.

Veselý, M. et al. (1990): Výškové zaměření a vyhodnocení svahu ZŠ ve Šlapanicích pro posouzení stability svahu. - MS FAST VUT Brno, katedra geodézie a geotechniky. 